\title{
INDEKS KELEMBABAN SUHU DAN RESPON FISIOLOGI SAPI BALI YANG DIPELIHARA SECARA FEED LOT PADA KETINGGIAN BERBEDA
}

\author{
NURIYASA I.M., DEWI G.A.M. K., BUDIARI N.L.G \\ madenuriyasa@yahoo.com
}

\begin{abstract}
ABSTRAK
Penelitian yang bertujuan untuk mengetahui kondisi iklim mikro dan respon fisiologi sapi Bali yang dipelihara secara feed lot pada ketinggian tempat berbeda yaitu di daerah dataran rendah, sedang dan tinggi. Penelitian lapangan dilaksanakan pada tiga ketinggian tempat yaitu pada peternak di Desa Sudimara, Tabanan (dataran rendah), Di Desa Sobangan (dataran sedang) dan di Desa Baturiti (dataran tinggi). Penelitian dilakukan dengan pengamatan langsung di lapangan (survey), pada masing-masing ketinggian tempat diamati 1o peternak (ulangan). Pengambilan sampel dilakukan dengan metode Purposive Random Sampling (Sugiyono, 2009). Ternak yang diamati adalah ternak berumur sama yang dapat dilihat dari jumlah gigi seri sebanyak dua buah (umur 2-3 tahun). Pengamatan dilakukan sebanyak 10 kali perjalanan survey. Hasil penelitian menunjukkan bahwa temperatur udara, kelembaban udara dan temperature humidity index kandang sapi di daerah dataran tinggi lebih rendah $(\mathrm{P}<0,05)$ daripada dataran sedang dan rendah. Tidak terjadi perbedaan yang nyata $(\mathrm{P}>0,05)$ pada variabel intensitas radiasi matahari dan kecepatan angin pada semua perlakuan. Temperatur kulit, temperatur rektal dan frekuensi pernafasan sapi yang dipelihara pada daerah dataran rendah adalah lebih tinggi $(\mathrm{P}<0,05)$ dibandingkan daerah dataran sedang dan tinggi. Berdasarkan hasil penelitian dapat disimpulkan bahwa kondisi iklim mikro kandang dan respon fisiologi sapi yang dipelihara di daerah dataran rendah lebih jelek dibandingkan dengan daerah dataran sedang dan tinggi.
\end{abstract}

Kata kunci: sapi bali, ketinggian tempat, iklim mikro, respon fisiologi

\section{TEMPERATURE HUMIDITY INDEX AND PHYSIOLOGICAL RESPONSES OF BALI CATTLE WITH FEEDLOT SYSTEM HOUSED AT DIFFERENT ALTITUDE}

\begin{abstract}
This study aims to determine micro-climate conditions and physiological responses of Bali cattle with feed lots system housed at different altitudes in upland, middleland lowland areas. Survey conducted on farmers at three different altitudes in which in Sudimara village, Tabanan (lowlands), in Sobangan village (middle land) and in the village of Baturiti (upland). Survey at each altitude are conducted at 10 different cattle farmers (10 replications). Sampling was done by purposive random sampling method (Sugiyono, 2009). Cows were observed are the same age that can be seen from the number of permanent incisors (aged 2-3years). The results showed that the air temperature, air humidity and temperature humidity index on a cow shed in the upland areas was lower $(\mathrm{P}<0.05)$ than the middle and lowland areas. No significant differences $(\mathrm{P}>0.05)$ in the variable intensity of solar radiation and wind speed on all treatments. Skin temperature, rectal temperature and respiratory rate of Bali cattle housed in lowland areas was higher $(\mathrm{P}<0.05)$ compared to middle and highland areas. Conclusions from the study ar emicroclimatic conditions of the cage and physiological responses of Bali cattle housed in lowland areas worse than the middle and highland areas.
\end{abstract}

Keyword: bali cattle, altitude,microclimate, physiological response

\section{PENDAHULUAN}

Pengembangan ternak sapi di Indonesia dan khususnya di Bali memiliki nilai sangat strategis dalam meningkatkan tingkat kesejahtraan masyarakat. Hampir setiap rumah tangga di Bali memiliki ternak seperti ternak sapi, kambing, babi, ayam dan kelinci terutama masyarakat petani peternak di pedesaan. Ternak ruminansia (sapi Bali) mampu merubah bahan pakan dengan kandungan serat kasar tinggi seperti rumput lapangan dan limbah pertanian menjadi daging, telur dan susu sebagai sumber protein hewani yang sangat diperlukan untuk meningkatkan tingkat kecerdasan masyarakat Indonesia (Wiguna, 2007). 
Penduduk Indonesia mayoritas (70-90\%) berdomisili di pedesaan yang sumber hidup utamanya adalah dari usaha pertanian dalam arti luas dalam upaya penyediaan komoditas pangan, kebun, ikan maupun ternak (Mastika, 2011).

Tumpuan ternak sapi sebagai sumber protein hewani masyarakat untuk mewujudkan swasembada protein hewani tahun 2014 akan dapat dicapai bila peternak telah memperhatikan fator-faktor pendukung pertumbuhan ternak seperti bibit, makanan dan lingkungan (Nuriyasa, 2012). Ketinggian tempat pemeliharaan (altitude) berdampak pada iklim mikro lokasi peternakan melalui perbedaan intensitas radiasi matahari yang diterima dan partisi pemanfaatannya (Yates, 1987).

Dalam proses produksi peternakan, unsur-unsur iklim yang dominan berpengaruh adalah temperatur dan kelembaban udara, radiasi matahari dan kecepatan angin (Esmay, 1978). Menurut pendapat Handoko (1995) unsur-unsur iklim ini lebih banyak dikendalikan oleh garis lintang dan ketinggian tempat dari permukaan laut. Yates (1987) menyatakan bahwa perbedaan intensitas radiasi matahari yang diterima permukaan bumi dan pemenfaatan radiasi matahari yang diterima permukaan bumi seprti untuk memanaskan tanah, udara, evapotranspirasi dan fotosintesis akan berpengaruh terhadap temperatur dan kelembaban udara. Esmay (1987) menyatakan temperatur dan kelembaban udara menentukan tingkat kenyaman ternak yang terindikasi dari nilai Temperature Humidity Index (THI). Menurut Sitaneapessy (1997) ketinggian tempat dari permukaan laut (altitude) sebagai pengendali iklim juga berpengaruh terhadap kualitas pakan ternak. Nuriyasa (2012) mendapatkan bahwa THI berpengaruh terhadap produktivitas ternak karena terjadi perbedaan efisiensi penggunaan pakan. Ternak yang dipelihara pada kondisi lingkungan dengan nilai THI lebih tinggi dari standar kebutuhan menyebabkan kebutuhan energi untuk hidup pokok meningkat sehingga energi yang dapat dipakai untuk pertumbuhan menurun.

Temperatur udara yang terukur di dalam kandang berasal dari pancaran radiasi gelombang pendek dan gelombang panjang dari radiasi matahari langsung, pantulan dan radiasi bauran dari atmosfer. Radiasi matahari yang mengenai bahan atap kandang akan dirubah oleh lapisan bagian atas atap menjadi gelombang panjang (panas), diantarkan ke lapisan bagian dalam dengan cara konduksi dan dipancarkan ke ruangan kandang. Pancaran radiasi gelombang panjang ini merupakan bagian paling dominan mempengaruhi temperatur terukur di dalam ruangan kandang. Besaran kelembaban udara relatif yang terukur di dalam kandang tergantung pada sumber air yang ada dalam kandang, kecepatan angin yang berembus dalam kandang dan temperatur udara sebagai faktor pengendali evaporasi (Nuriyasa, 1991).

Pergeseran temperatur dari kisaran nyaman pada ternak sapi sudah dapat dipastikan ternak akan mengalami cekaman baik cekaman panas (hipertermia) atau cekaman dingin (hipotermia). Ternak akan memberikan respon awal dalam bentuk perubahan tingkah laku, peningkatan aktivitas sistem respiratoris dan kardiovaskularis. Jika respon awal belum tercapai keadaan homeostatik, akan timbul respon lanjutan berupa perubahan-perubahan pada sistem hormonal, enzimatik dan metabolik. Kalau pada respon lanjutan ini belum juga tercapai keadaan homeostatik maka ternak akan mengalami berbagai gejala penyakit yang disertai rendahnya efisiensi produksi dan reproduksi (Esmay, 1978).

Mount (1979) mendapatkan bahwa ada beberapa perubahan tingkah laku yang menonjol pada ternak mamalia yang mengalami cekaman panas adalah: mengurangi konsumsi ransum, meningkatkan konsumsi air, mengurangi aktivitas gerak tubuh, mempercepat frekuensi pernafasan. Kondisi ini menyebabkan kebutuhan energi untuk hidup pokok meningkat dan penggunaan energi untuk pertumbuhan menjadi lebih rendah.

\section{MATERI DAN METODE}

\section{Ternak}

Sapi yang digunakan dalam penelitian ini adalah sapi Bali yang telah dikelompokkan berdasarkan umur yang dipelihara pada tiga ketinggian tempat yaitu : Di Desa Sudimara, Tabanan (dataran rendah), Desa Sobangan, Mengwi, Denpasar (dataran sedang) dan Desa Baturiti (dataran tinggi).

\section{Ransum}

Ternak sapi yang dipakai penelitian diberi ransum dasar rumput lapangan tanpa diberi tambahan konsentrat.

Tempat dan Lama Penelitian

Penelitian lapangandilakukanselama 4 minggu, dengan 10 kali perjalanan survey. Pengambilan data dilakukan pada tiga ketinggian tempat pemeliharaan yaitu di Desa Sudimara, Tabanan dengan ketinggian tempat ( $15 \mathrm{~m} \mathrm{dpl),} \mathrm{di} \mathrm{Desa} \mathrm{Sobangan,} \mathrm{Denpasar} \mathrm{dengan}$ ketinggian tempat $250 \mathrm{~m} \mathrm{dpl}$ (dataran sedang) dan di Desa Baturiti, Tabanan dengan ketinggian tempat 750 $\mathrm{m}$ dpl (dataran tinggi).

\section{Rancangan Percobaan}

Penelitian lapangan dilaksanakan pada tiga ketinggian tempat yaitu pada peternak di Desa Sudimara, Tabanan (dataran rendah), Di Desa Sobangan (dataran 
sedang) dan di Desa Baturiti (dataran tinggi). Penelitian dilakukan dengan pengamatan langsung di lapangan (survey), masing-masing lokasi penelitian diamati pada enam peternak. Pengambilan sampel dialakukan dengan metode Purposive Random Sampling (Sugiyono, 2009). Ternak yang diamati adalah ternak berumur sama pada tiap blok yang dapat dilihat dari jumlah gigi seri sebanyak dua buah (umur 2-3 tahun). Pengamatan dilakukan sebanyak 10 kali perjalanan survey. Penelitian menggunakan Rancangan Acak Kelompok (RAK) dengan 10 kali Ulangan. Pengelompokan dilakukan berdasarkan umur sapi. Perlakuan yang dipergunakan dalam penelitian ini adalah ketinggian tempat pemeliharaan yang terdiri dari: pemeliharaan pada daerah dataran rendah (T1), pemeliharaan pada daerah dataran sedang (T2) dan pemeliharaan pada daerah dataran tinggi (T3).

\section{Variabel yang Diamati}

1. Temperatur Udara, Kelembaban Udara dan THI. Data temperatur dan kelembaban udara dalam kandang diukur dengan menggunakan thermohygrometer digital tipe $\mathrm{CE}$ 11/08 . Pengukuran dilakukan tiga kali sehari yaitu pagi hari pada pukul 7.30 wita, siang hari pada pukul 13.30 wita dan sore hari pada pukul 17.30 wita. Temperatur rata-rata harian didapat dengan menggunakan formulasi Handoko (1995) sebagai berikut:

Temperature Humidity Index (THI) dihitung dengan formulasi empiris menurut Esmay (1978) sebagai berikut: $\mathrm{THI}=0,4(\mathrm{Tdb}+\mathrm{Twb})+15$, dimana THI: Temperature Humidity Index, Tdb: Temperatur bola kering $\left({ }^{\circ} \mathrm{F}\right)$, Twb: Temperatur bola basah $\left({ }^{\circ} \mathrm{F}\right)$

2. Intensitas Radiasi Matahari. Pengukuran intensitas radiasi matahari dilakukan dengan menggunakan light meter digital merk Lutron tife LX-103 dan pengukuran dilakukan tiga kali sehari yaitu pukul 7.30, 13.30 dan 17.30 wita.

3. Kecepatan Angin dalam Kandang. Kecepatan angin di masing-masing lokasi penelitian dalam diukur dengan menggunakan anemometer digital LM-81AM dan dilakukan tiga kali sehari yaitu pada pukul 7.30, 13.30 dan 17.30 wita.

\section{Analisis Data}

Data yang diperoleh pada penelitian ini dianalisis dengan sidik ragam. Bila perlakuan berpengaruh nyata pada variable respon, dilanjutkan dengan uji jarak berganda dari Duncan pada taraf 5\% (Steel dan Torrie, 1986).

\section{Peralatan Pengukur Variabel Iklim}

Termohygrometer digital tipe CE 0197. Dipakai untuk mengukur temperatur dan kelembaban udara di lokasi peternakan
Imfra Red Termometer Digital. Alat ini dipakai untuk mengukur temperature kulit ternak. Pengukuran dilakukan pada empat tempat yaitu: kepala, leher, punggung dan pangkal ekor. Hasil pengukuran ke empat lokasi kemudian dirata-ratakan untuk mendapatkan temperatur kulit yang representatif.

Anemometer Digital. Diperlukan untuk mengukur kecepatan angin pada lokasi penelitian.

Light meter digital tipe LX-103. Digunakan untuk mengukur intensitas radiasi matahari yang sampai pada ruangan kandang penelitian dan intensitas radiasi di luar kandang penelitian.

Timbangan Elektrik Iconix. Kapasitas $2000 \mathrm{~kg}$ dengan kepekaan $200 \mathrm{~g}$ untuk menimbang berat sapi. Timbangan Elektrik Shoenle, kapasitas 2 kg, untuk menimbang sisa ransum.Timbangan Salter, kapasitas 50 $\mathrm{kg}$ untuk menimbang jumlah ransum yang diberikan.

\section{HASIL DAN PEMBAHASAN}

\section{Iklim Mikro}

Temperatur udara dalam kandang sapi di daerah dataran tinggi (T3) adalah $24,89{ }^{\circ} \mathrm{C}$, sedangkan temperatur kandang sapi di daerah dataran sedang (T2) dan daerah dataran rendah (T1) masing-masing 4,58\% dan 14,18\% lebih tinggi daripada $\mathrm{T}_{3}$ yang secara statistik berbeda nyata $(\mathrm{P}<0,05)$, seperti pada Tabel 1. Kandang pada $\mathrm{T}_{3}$ mempunyai kelembaban udara paling rendah yaitu $60,34 \%$, sedangkan kandang sapi pada T2 dan T1 masing-masing 6,65\% dan 14,56\% lebih tinggi $(\mathrm{P}<0,05)$ dibandingkan dengan $\mathrm{T}_{3}$. Tidak terjadi perbedaan yang nyata $(\mathrm{P}>0,05)$ antara perlakaun $\mathrm{T} 1, \mathrm{~T} 2$ dan $\mathrm{T}_{3}$ terhadap variabel intensitas radiasi matahari. Kecepatan angin pada kandang sapi T1, T2 dan $\mathrm{T}_{3}$ tidak menunjukan perbedaan yang nyata $(\mathrm{P}>0,05)$.

\begin{tabular}{|c|c|c|c|c|}
\hline Variabel & $\mathrm{T} 1$ & T2 & T3 & SEM \\
\hline Temperatur Udara $\left({ }^{\circ} \mathrm{C}\right)$ & $28,42^{a}$ & $26,03^{b}$ & $24,89^{c}$ & 1,02 \\
\hline Kelembaban Udara (\%) & $69,12^{a}$ & $64,35^{\mathrm{b}}$ & $60,34^{c}$ & 2,54 \\
\hline Temperatur Humidity Index (THI) & $73,24^{a}$ & $70,06^{b}$ & $68,04^{c}$ & 2.02 \\
\hline Intensitas Radiasi Matahari (lux) & $44,08^{a}$ & $43,3^{a}$ & $38,74^{a}$ & 0,86 \\
\hline Kecepatan Angin (m/dt) & $2,43^{a}$ & $0,88^{a}$ & $2,63^{a}$ & 0,52 \\
\hline \multicolumn{4}{|c|}{$\begin{array}{l}\text { T1 : Ketinggian Tempat Pemeliharaan } 15 \mathrm{~m} \text { dpl (Dataran Rendah) } \\
\text { T2: Ketinggian Tempat Pemeliharaan } 255 \mathrm{~m} \text { dpl (Dataran Sedang) }\end{array}$} & $\begin{array}{l}\text { T2 : Ketinggian Tempat Pemeliharaan } 255 \text { m dpl (Dataran Sedang) } \\
\text { T3 : Ketinggian Tempat Pemeliharaan } 758 \text { m dpl (Dataran Tinggi) }\end{array}$ \\
\hline \multicolumn{5}{|c|}{$\begin{array}{l}\text { Superskrip yang sama pada baris yang sama menunjukkan perbedaan tidak nyata } \\
(\mathrm{P}>0,05)\end{array}$} \\
\hline \multicolumn{5}{|c|}{ SEM :Standard Error of The Treatment Means } \\
\hline
\end{tabular}

Bibit unggul, pakan cukup secara kualitas dan kuantitas tidak akan dapat memberikan performas maksimal pada ternak bila tidak didukung oleh faktor lingkungan yang nyaman. Sebaliknya faktor lingkungan yang nyaman tidak akan banyak membantu bila ternak yang dipelihara mempunyai potensi genetik rendah dan pakan yang diberi tidak cukup secara kualitas dan 
kuantitas (Nuriyasa, 2012). Temperatur, kelembaban udara, radiasi matahari dan kecepatan angin merupakan unsur-unsur iklim yang paling berpengaruh terhadap kenyamanan ternak dalam kandang (Larry, 2013).

Temperatur udara dalam kandang sapi yang terletak di daerah dataran tinggi ( $\mathrm{T}_{3}$ ) lebih rendah dibandingkan dengan kandang sapi yang ada di daerah dataran sedang (T2) dan dataran rendah (T1). Kondisi ini disebabkan karena intensitas radiasi matahari yang masuk dalam ruangan kandang pada kandang di T3 lebih rendah daripada T2 dan T1 (Tabel 1). Mount (1979) menyatakan intensitas radiasi matahari yang lebih rendah menyebabkan panas (radiasi gelombang panjang) yang ditimbulkan di ruangan kandang menjadi lebih rendah. Pendapat ini didukung oleh Handoko (1995) dan Rasul et al. (2013). yang menyatakan bahwa unsurunsur iklim tersebut dikendalikan oleh garis lintang (latitude) dan ketinggian tempat dari permukaan laut (altitude). Pendapat ini didukung oleh Meyer et al. (2010) yang menyatakan bahwa temperatur lingkungan pada sapi yang dikandangkan lebih rendah $\left(75,9^{\circ} \mathrm{F}\right)$ dibandingkan dengan temperature lingkungan sapi yang digembalakan $\left(77,2^{\circ} \mathrm{F}\right)$. Praks (2013) menyatakan bahwa batas atas temperatur udara adalah $25^{-} 26^{\circ} \mathrm{C}$. Berdasarkan data temperatur udara, kandang sapi yang berada pada daerah dataran sedang mengalami cekaman panas, kandang sapi yang berada pada daerah dataran sedang berada pada titik kritis atas dan kondisi kandang di daerah dataran tinggi berada dalam kondisi nyaman.

Kelembaban udara relatif mencerminkan banyaknya uap air yang terkandung di udara secara faktual dibandingkan dengan uap air jenuh dengan satua persen (Handoko, 1995). Kelembaban udara dalam kandang sapi di daerah dataran rendah lebih tinggi daripada daerah dataran sedang dan tinggi. Intensitas radiasi matahari pada kandang sapi di daerah dataran rendah (44,08 lux) lebih tinggi dibandingkan dengan daerah dataran sedang (43,30 lux) dan dataran tinggi (38,74 lux), seperti pada Tabel 1 .

Temperatur udara lebih tinggi menyebabkan proses evapotranspirasi meningkat sehingga kandungan uap air di udara meningkat. Kondisi ini menyebabkan kelembaban udara dalam kandang di daerah dataran rendah paling tinggi. Pendapat ini didukung oleh Ogunjimi et al. (2008) yang menyatakan bahwa laju evaporasi berbanding lurus dengan temperatur udara dan kecepatan angin. Pendapat yang sama dikemukan oleh Nuriyasa (1991) bahwa besaran kelembaban udara relatif yang terukur di dalam kandang tergantung pada sumber uap air yang ada dalam kandang, kecepatan angin dan temperature udara sebagai faktor pengendali laju evaporasi.

Hasil berbeda didapatkan oleh Meyer et al. (2010) kelembaban udara disekitar ternak yang dikandangkan $(76,5 \%)$ tidak berbeda nyata dengan kelembaban udara tempat sapi digembalakan (75,6\%). Perbedaan data ini disebabkan karena pengukuran dilakukan pada areal peternakan yang sama, dengan ketinggian tempat pemeliharaan (altitude) yang sama.

Intensitas radiasi matahari yang masuk ke dalam kandang pada ketinggian tempat berbeda berkisar antara 38,74 lux-44,08 lux. Intensitas radiasi matahari yang masuk ke dalam kandang sapi di daerah dataran rendah (44,08 lux) sedangkan pada daerah dataran sedang ( 43,3 lux) dan dataran tinggi $(38,74$ lux), seperti pada Tabel 1 .

Daerah dataran tinggi atmosfernya lebih keruh daripada daerah dataran sedang dan rendah. Kondisi ini menyebabkan lebih banyak radiasi matahari yang diabsorbsi dan direfleksi oleh atmosfer sehingga intensitas radiasi yang diterima bumi menjadi lebih rendah. Yates (1987) menyatakan bahwa makin tinggi intensitas radiasi matahari yang diterima bumi dan makin rendah pemanfaatan radiasi matahari yang dipergunakan untuk panas laten dan fotosintesis akan berdampak pada kondisi dimana pemanfaatan radiasi matahari untuk memanaaskan bumi dan atmosfer lebih tinggi. Partisi pemanfaatan radiasi matahari untuk pemanaskan atmosfer dan bumi ini akan terukur sebagai temperatur udara dalam kandang sapi.

Ketinggian tempat pemeliharaan berbeda tidak berpengaruhnyataterhadapkecepatananginyangmasuk ke dalam kandang. Rozari (1987) menyatakan bahwa daerah dataran sedang dan dataran tinggi mempunyai lapisan gesek lebih tinggi sebagai penghambat laju aliran angin. Kandang sapi yang diamati pada ketiga ketinggian tempat berbeda semuanya berada di tengah ladang yang dikelilingi pagar sehingga laju aliran angin tertahan. Kondisi ini menyebabkan kecepatan angin yang masuk ke dalam kandang tidak berbeda.

Berdasarkan perhitungan nilai THI, kondisi kandang sapi di daerah dataran tinggi (THI: 68,04) dan dataran sedang (THI: 70,86) berada dalam kondisi nyaman sedangkan kondisi kandang pada daerah dataran rendah $(73,24)$ berada dalam kondisi tidak nyaman. AlKatanani et al. (2002) menyatakan bahwaunsur-unsur iklim mikro yang berpengaruh terhadap produktivitas ternak diantaranya: temperatur udara, kelembaban relatif udara $(\mathrm{Rh})$, radiasi matahari dan ventilasi atau pergerakan udara. Interaksi antara temperatur dan kelembaban udara menghasilkan temperature humidity index (THI).

Data pada Tabel 1 menunujukkan bahawa temperature dan kelembaban udara rata-rata kandang sapi yang berada pada daerah dataran rendah lebih tinggi daripada daerah dataran sedang dan tingggi. Kondisi ini menyebabkan Temperature Humidity Index 
(THI) kandang sapi di daerah dataran rendah lebih tinggi daripada dataran sedang dan dataran tinggi. Nuriyasa (2012) menyatakan THI merupakan salah satu indikator tingkat kenyamanan ternak. Makin tinggi nilai THI dari kisaran optimum makin tinggi tingkat cekaman panas yang dialami oleh ternak.

\section{Variabel Fisiologi}

Temperatur kulit sapi Bali yang dipelihara pada T1 adalah paling tinggi $\left(37,89^{\circ} \mathrm{C}\right)$ yang secara statistik tidak berbeda nyata $(\mathrm{P}>0,05)$ dibandingkan dengan T2 namun berbeda nyata $(\mathrm{P}<0,05)$ dibandingkan dengan $\mathrm{T}_{3}$ (Tabel 2). Temperatur rektal sapi yang dipelihara pada $\mathrm{T} 3$ paling rendah $\left(39,02^{\circ} \mathrm{C}\right)$, sedangkan temperatur rektal pada T2 adalah 1,08\% lebih tinggi ( $\mathrm{P}>\mathrm{O}, 05)$ dibandingkan dengan $\mathrm{T} 3$, sedangkan temperature rektal sapi pada $\mathrm{T} 1$ adalah $1,80 \%$ lebih tinggi $(\mathrm{P}<0,05)$ dibandingkan dengan $\mathrm{T} 3$. Frekuensi pernafasan sapi pada daerah $\mathrm{T} 1$ adalah $58,16 \mathrm{kali} /$ menit sedangkan frekuensi pernafasan sapi pada T2 dan $\mathrm{T}_{3}$ masing-masing 9,75\% dan 13,91\% lebih rendah $(\mathrm{P}<0,05)$ dibandingkan dengan $\mathrm{T} 1$.

Tabel 2. Fisiologi Sapi Penggemukan (Umur 2-3 Tahun) pada Ketinggian Tempat Pemeliharaan Berbeda

\begin{tabular}{lcccc}
\hline \multicolumn{1}{c}{ Variabel } & T1 & T2 & T3 & SEM \\
\hline Temperatur kulit $\left({ }^{\circ} \mathrm{C}\right)$ & $37,89^{\mathrm{a}}$ & $37,64^{\mathrm{ab}}$ & $36,66^{\mathrm{b}}$ & 0,33 \\
Temperatur rektal (\%) & $39,72^{\mathrm{a}}$ & $39,44^{\mathrm{ab}}$ & $39,02^{\mathrm{b}}$ & 0,22 \\
Frekuensi pernafasan(kali/menit) & $58,16^{\mathrm{a}}$ & $52,49^{\mathrm{b}}$ & $50,07^{\mathrm{C}}$ & 2,39 \\
\hline 1) $\mathrm{T} 1$ : Ketinggian Tempat Pemeliharaan $15 \mathrm{~m} \mathrm{dpl}$ (Dataran Rendah) & \\
& $\mathrm{T} 2:$ Ketinggian Tempat Pemeliharaan $255 \mathrm{~m} \mathrm{dpl}$ (Dataran Sedang) \\
& T3: Ketinggian Tempat Pemeliharaan $758 \mathrm{~m} \mathrm{dpl}$ (Dataran Tinggi) \\
2) Superskrip yang sama pada baris yang sama menunjukkan perbedaan tidak nyata \\
(P>0,05) \\
3) SEM :Standard Error of The Treatment Means.
\end{tabular}

Temperatur kulit ternak sapi dipengaruhi oleh iklim makro lokasi peternaka (Lysyk, 2008), warna dan tebal bulu (Finch, 1986). Temperatur kulit sapi Bali berkisar antara $36,66^{\circ} \mathrm{C}-37,89^{\circ} \mathrm{C}$. Lysyk (2008) menyatakan temperatur kulit sapi Angus adalah $29{ }^{\circ} \mathrm{C}$ dan sapi FH $32{ }^{\circ} \mathrm{C}$. Perbedaan data hasil pengukuran ini disebabkan karena perbedaan iklim makro tempat pengukuran antara daerah sub tropis dengan daerah tropis. Perlakuan ketinggian tempat pemeliharaan yaitu di daerah dataran rendah (T1) menyebabkan temperature kulit lebih tinggi dibandingkan dengan sapi di daerah tinggi ( $\mathrm{T}_{3}$ ), namun tidak berbeda dengan daerah dataran sedang (T2). Hal ini disebabkan karena temperatur dan kelembaban udara pada kandang sapi di daerah (T1) lebih tinggi daripada (T3), sesuai dengan pendapat Lysyk (2008). Intensitas radiasi matahari yang diterima oleh kandang di daerah $\mathrm{T} 1$ paling tinggi (44,08 lux) yang disusul oleh T2 dan T3 masing-masing 43,3 lux dan 38,74 lux.

Perlakuan $\mathrm{T}_{3}$ (dataran tinggi) menyebabkan temperatur rektal paling rendah $\left(39,02^{\circ} \mathrm{C}\right)$ sedangkan perlakuan T2 (dataran sedang) dan T1 (dataran rendah) masing-masing $39,44^{\circ} \mathrm{C}$ dan $39,72^{\circ} \mathrm{C}$. Data iklim mikro hasil penelitian menunjukkan bahwa temperatur dan kelembaban udara serta nilai THI kandang sapi yang berada pada daerah dataran tinggi ( $\left.\mathrm{T}_{3}\right)$ lebih rendah dibandingkan dengan T2 dan T1.

Kondisi iklim mikro yang nyaman (comfort zone) menyebabkan sapi di daerah dataran tinggi mampu melakukan proses homeostatis dengan baik sehingga temperatur rektal lebih rendah daripada di daerah dataran sedang dan rendah. Sebaliknya pada daerah dataran rendah, ternak sapi mengalami cekaman panas yang diindikasikan oleh nilai THI $(73,24)$ di atas kebutuhan optimum (72), rekomendasi dari Esmay (1978). Kondisi cekaman panas menyebabkan sapi lebih sukar melepaskan kelebihan panas tubuhnya baik dengan cara konduksi, konveksi, evaporasi dan radiasi sehingga berdampak pada peningkatan temperatur rektal.

Frekuensi pernafasan sapi Bali pada ketinggian tempat pemeliharaan berbeda berkisar antara 50,0758,16 kali/menit. Carrol et al. (2012) dan Farooq et al. (2010) menyatakan frekuensi pernafasan pada sapi dipengaruhi oleh temperature kandang. Makin tinggi pergeseran suhu kandang dari kebutuhan optimal maka frekuensi pernafasan makin tinggi. Hasil penelitian Arrilage at al. (1992) mendapatkan bahwa frekuensi pernafasan sapi holstein, guernsey, brown swiss, jersey dan ayshire yang dipelihara di daerah tropis masingmasing 57,1; 58,6; 55,1; 54,2 dan 51 kali/menit. Hal ini menunjukkan bahwa frekuensi pernafasan sapi masih berada dalam kisaran normal. Frekuensi pernafasan sapi bali yang dipelihara didaerah dataran rendah (T1) lebih tinggi daripada sapi di daerah dataran sedang (T2) dan daerah dataran tinggi ( $\mathrm{T}_{3}$ ), seperti pada Tabel 2.

Mahardika (1996) dan Nuriyasa et al. (2010) menyatakan peningkatan frekuensi pernafasan adalah merupakan usaha ternak untuk mempercepat proses pelepasan panas dengan cara evaporasi dari saluran pernafasan. Cekaman panas dialami oleh sapi di daerah dataran rendah yang diindikasikan oleh temperatur, kelembaban udara dan nilai THI yang lebih tinggi daripada daerah dataran sedang dan tinggi menyebabkan sapi di daerah dataran rendah meningkatkan frekuensi pernafasannya agar dapat menyeimbangkan produksi panas dengan panas yang dilepas ke lingkungan.

Evaporasi dari saluran pernafasan merupakan salah satu proses homeostatis yang dilakukan ternak sapi dengan mengambil panas laten (laten heat) dari dalam tubuh ternak sehingga panas tubuh sebagian dapat dilepaskan ke lingkungan. Hasil penelitian yang sama didapatkan oleh Al-Kanani et al. (2002) dimana sapi FH yang dikandangkan mempunyai frekuensi pernafasan 54 kali/menit sedangkan sapai yang 
digembalakan mempunyai frekuensi pernafasan 82 kali/menit. Gaughan et al. (2000) mendapatkan bahwa sapi persilangan antara Hereford, Angus dan Simmental yang dipelihara pada kondisi lingkungan dengan THI 79,2 menyebabkan frekuensi pernafasan laju respirasi 109,5 kali/menit dibandingkan denganTHI 78,9 yaitu 107,6 kali/menit.

Dapat disimpulkan bahwa: (1) Iklim mikro kandang sapi yang berada di daerah dataran tinggi lebih baik daripada di daerah dataran sedang dan rendah. (2) Respon fisiologi sapi yang dipelihara di daerah dataran tinggi lebih baik daripada di daerah dataran sedang dan rendah.

\section{SARAN}

Pengembangan sapi Bali penggemukan sebaiknya dilakukan di daerah dataran tinggi agar ternak ctidak mengalami cekaman panas, produktivitas meningkat sehingga pendapatan petani dapat meningkat, swasembada protein hewani dapat tercapai sesuai dengan rencana pemerintah.

\section{UCAPAN TERIMAKASIH}

Penulis mengucapkan banyak terima kasih kepada LPPM Unud yang telah memberikan bantuan danapenelitian BOPTN melaui Program Magister Ilmu Peternakan, Program Pascasarjana, Universitas Udayana sehingga penelitian ini dapat terlaksana.

\section{DAFTAR PUSTAKA}

Al-Katanani, Y M, Paula-Lopes F F., and Hansen P J. 2002. "Effect of season and exposure to heat stress on oocyte competence in holstein cows." Journal of Dairy Science 85 (2002): 390-396

Carroll, J.A, Burdick N.C., Chase C.C., Colemen S.W., dan Spier D.E .2012. Influence of environmental temperature on the physiological, endocrine, and immune responses in livestock exposed to a provocative immune challenge .Proceedings of the 7th International Congress on Farm Animal Endocrinology, Bern, Switzerland, August 24-26, 2011.Volume 43, Issue 2, August 2012, Pages 146-153

Finch, V.A. 1986. Body temperature in beef cattle: its control and relevance to production in the tropic. J. Anim. Sci (62): 531-542

Farooq, U., Samad H.A., Shehzad F., and Qayyum A. 2010. Physiological responses of cattle to heat stress. World Appllied Science Journal (8): 38-43.

Larry, E.C. 2013. Climate change imfacts on dairy cattle. Departement of animal Science, Cornell University, Ithaca, New York 14853

Lysyk, T.J. 2008. Effect of ambient temperature and cattle skin temperature on engorgement of dermacentor Anderson. Journal of Medical Entomology 45 (6): 531-542

Mahardika, I.G. 1996. Kinerja Kerbau Betina pada Berbagai Beban Kerja serta Implikasinya terhadap Kebutuhan Energi dan Protein Pakan. (Disertasi) Program Pascasarjana, IPB, Bogor.

Mastika, I.M. 2011. Potensi Limbah Pertanian dan Industri Pertanian serta Pemanfaatannya untuk Pakan Ternak. Penerbit Universitas Udayana.

Meyer, D.M, M. J. Brouk, and L. C. Hollis. 2010. Effect of Heat Stress on Dairy Calves. Kansas State University.

Nuriyasa, I.M. Puspani E., Sumatra I. G. N. 2010. Peningkatan Efisiensi Produksi Ayam Petelur Melalui Peningkatan Kenyamanan Kandang di Desa Bolangan, Journal Pengabdian Kepada Masyarakat, ISSN: 1412-0925.

Praks, J. 2013. The effect of temperature stress on dairy cows . (http://www.guaranteedweather.com/page.php?content_ id=25). Disitir 26 Nopember 2013.

Rasul, G., Chaudhry Q.Z, Mahmood A., dan Hyder K.W. 2013. Effect of temperature rise on crop growth and productivity. Pakistan Journal of Meteorology vol.8 issue (15): 53-62.

Sugiono. 2005. Statistika untuk penelitian. Cetakan ke tujuh. Alfabeta. CV. Bandung.

Tillman, A.D., Hartadi H., Reksohadiprojo S., Prawirokusumo S. dan Lebdosoekojo S. 1984. Ilmu Makanan Ternak Dasar. Gajah Mada University Press. Yogyakarta.

Wiguna, I.W., Inggriati N.W.T., Arya N., Budiana N., dan Chandra W. 2007. Pengembangan Agribisnis Pengolahan Pakan dan Limbah Peternakan di Kabupaten Tabanan Bali. BPTP, Bali. 